\title{
除脳ネコ脳幹電気刺激により誘発される 発声時の内喉頭筋と呼吸筋活動の解析
}

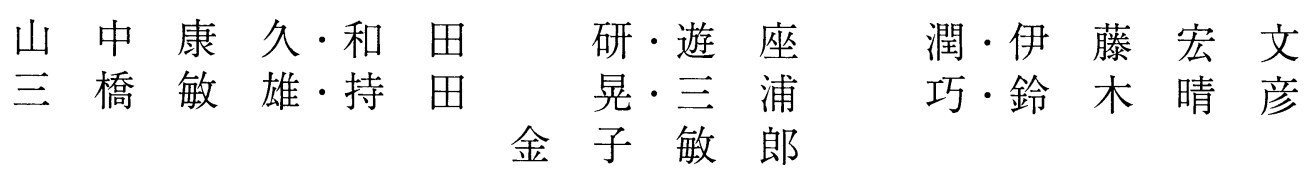

\section{EMG Activities of the Intralaryngeal and Ventilatory Muscles During Electrically Induced Vocalization in Decrebrate Cats}

\author{
Yasuhisa Yamanaka, Ken Wada, Jun Yuza, \\ Hirofumi Ito, Toshio Mitsuhashi, Akira Mochida, \\ Takumi Miura, Haruhiko Suzuki and Toshio Kaneko
}

\begin{abstract}
Vocalization was induced by repetitive electrical stimulation $(0.2 \mathrm{~ms}, 25$ to $80 \mu \mathrm{A}, 60$ to $100 \mathrm{~Hz}$, lasting for 5 to $30 \mathrm{~s}$ ) delivered to the brainstem (Horsley Clarke coordinates: A 1.5 to P 5.0, L or $\mathrm{R} 1.5$ to $5.5, \mathrm{H}-3.0$ to -9.0 ) in unanesthetized precollicular-postmammilary decerebrate cats. During induced vocalization, the activities of both inspiratory (diaphragm) and expiratory (rectus abdominis) muscles were augumented. The stimulation also bilaterally augmented the activities of the abductor (posterior cricoarytenoid) and adductor (thyroarytenoid) muscles of the vocal folds during inspiration and expiration, respectively. The stimulation initiated in either inspiratory or expiratory phase reset the spontaneous respiratory rhythm. Following inspiration due to the activation of the diaphragm and abductor muscle of the vocal cords, expiration with vocalization and inspiration were alternately induced with a newly developed rhythm. This suggested that the tonic electrical stimulation delivered to the higher brainstem can alter rhythm generation of spontaneous respiration. Persistent opening of a T-tube inserted into the trachea decreased respiratory cycle. Although opening of the T-tube during vocalization decreased subglottic pressure, the expiratory phase did not abruptly terminated. It was suggested that the feedback input from the mechanoreceptors in the laryngeal mucosa was less important than the vagal feedback from the alveolar stretch receptors to maintain respiratory cycle during the induced vocalization.
\end{abstract}

Key words : decerebrate cat, electrical brainstem stimulation, induced vocalization, EMG, respiratory rhythm

$$
\text { はじめに }
$$

安静呼吸においては，呼息時に声門は閉鎖せず，気道は 開大しているが, 発声時においては安静呼吸時とは異なり, 呼息時に声門が閉鎖されている。この様に発声に伴って, 喉頭運動は呼吸運動と密接に関連して制御されている。呼 吸運動に関しては中枢性りズム形成機構が橋・延髄に存在 すること1)，また迷走神経を介する求心性入力により，呼 吸周期が制御されていることが知られている ${ }^{2)}$. 内喉頭筋 支配運動ニューロンは延髄の疑核に存在し，その興奮性は 呼吸のリズム形成機構からの出力および呼吸に伴う求心性 入力によって影響を受けることが明かとなっている ${ }^{3-6)}$. また喉頭粘膜からの求心性入力によっても, その興奮性が 変化することが明かとなっている77.
発声に際しては，これら脳幹に存在する神経機構が上位 中枢によって協調のとれた制御を受けることが必要である。 除脳ネコの脳幹・橋に加えた電気刺激により発声が誘発さ れる ${ }^{8 \sim 12)}$. また，発声誘発部位の尾側を破壊することによ り吻側に加えた電気刺激の効果がなくなることが報告され ている ${ }^{12)}$.これらのことは, 上位脳幹が, 下位脳幹に存在 する内喉頭筋と呼吸筋運動を統合する発声に必要な基本的 神経機構を制御していることを示唆する。

本研究では, 発声における内喉頭筋と呼吸筋運動の上位 中枢による制御様式を解明することを目的とした。そのた めに, 無麻酔除脳ネコにおいて上位脳幹の異なる部位に微 小電気刺激を加え, 発声誘発部位を同定した。次に誘発さ れた発声における内喉頭筋および呼吸筋の筋電図活動，お よび呼吸周期の変化を安静呼吸時と比較解析した。また,

千葉大学医学部耳鼻咽喉科学教室

Department of Otolaryngology, School of Medicine, Chiba University, Chiba 
刺激により誘発された発声に伴う呼吸周期の形成における 求心性入力の機能的役割を明かにするために, 気管切開を 行い声門下圧を変化させ，その効果を解析した。

\section{実 験 方 法}

実験にはネコ $(\mathrm{n}=6$; 体重2.9 4.5kg) を用い, ハロ セン麻酔下に, 前頸部皮膚正中に舌骨から胸骨上部まで縦 切開を加えた. 胸鎖乳突筋, 胸骨舌骨筋を左右に偏移させ, 喉頭および気管を露出した。第 $4 \sim 7$ 気管輪で気管切開を 行い, T-tube（光研社 \#3304, 0.D. $8.0 \mathrm{~mm}$ ) を挿入し, 気管背側を走行する反回神経を損傷せぬように注意を払っ て，結紮固定した。声門閉鎖筋である甲状披裂筋（TA）， 声門開大筋である後輪状披裂筋 (PCA) と, 吸息筋であ る横隔膜 (DA), 補助呼息筋である腹直筋 (RA) に, 筋 電四記録用 $50 \mu \mathrm{m}$ 双極ステンレスワイヤ電極を刺入した。 両側総頸動脈を結紮し, T-tube 気管口を皮膚外に突出さ せ, 術創を縫合した後, 上丘前縁と乳頭体後縁を結ぶレべ ルで除脳した。

脳定位固定装置に除脳ネコを固定し, 麻酔から回復後, タングステン微小電極（直径 $200 \mu \mathrm{m}$, 先端抵抗 $0.5 \sim 1$ $M \Omega)$ を中脳から橋にかけての網様体腹外側部に刺入し, $0.5 \mathrm{~mm}$ 間隔で発声誘発部位の検索を行った。連続微小電

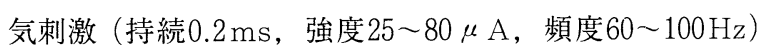
を 5 〜 30秒間加え, 最小間值で発声を誘発できる部位（以 後, 発声誘発部位と表現する) に電極を固定した. 実験中 の刺激強度は間值の1.5倍を用い, 以後刺激パラメーター は変化させなかった.

筋電図は生体用増幅器 (日本光電社 AB-651J) にて増 幅し，オシロスコープに表示モニターした．声門下圧の変 化はT-tube 気管口を開閉することで行った。 そのために T-tube 気管口にSwan-Ganz カテーテル (Baxter Heal thcare 社 model 93A-821H-7.5F) の先端を固定し, 先端 のバルーンを収縮・膨張させて気管口を開閉し, 同時に声 門下圧の測定を行った. 筋電図, 声門下圧, 電気刺激のモ ニターパルスは誘発された発声の音声とともに FM デー タレコーダー（TEAC 社 MR-30, DC〜10kHz）を用いて 磁気テープに記録した. off-line 処理により横隔膜筋活動 または声門閉鎖筋筋活動の開始時点を基準にし, 呼吸周期 を算定した。

実験中, 直腸温をモニターし, 保温マットおよび赤外線 ランプを用いて体温を $36 \sim 38^{\circ} \mathrm{C}$ に保った. End-tidal $\mathrm{CO}_{2}$ はガスモニター（NEC-SANEI, model 1H21A）を用い てモニターし，0.3〜0.4 vol\%に維持されていることを確 認した.

実験終了後, 刺激電極より $20 \mu \mathrm{A}, 20$ 秒間の直流電流を 通流し, 微小破壊巣を作成した。脳幹を $10 \%$ ホルマリンで 固定し, $50 \mu \mathrm{m}$ 凍結切片を作成し, Nissl 染色後, 刺激部 位を組織学的に検索した.

\section{実 験 結 果}

\section{1. 発声誘発部位の検索}

発声誘発部位は橋腹外側部, 内側毛帯 (ML) と錐体路 (P) 近傍の脳幹網様体（RF）に限局していた（図 $1 \mathrm{~A}$, B). 吻尾側方向には長く広がり, 尾側ほど腹内側に位置 し, 延髄のレベルまで広がっていた（図１Ｃ）。刺激閾值 は, 橋吻側部に比べて橋尾側部や延髄において高くなる傾 向があった. 橋吻側の発声誘発部位の背側部で, しばしば 刺激により呼吸筋筋活動の増大のみが誘発された。しかし, 内喉頭筋の周期的な筋活動の増大のみが誘発された部位は 存在せず, 発声誘発時は常に, 内喉頭筋と呼吸筋筋活動の 増大は同調して誘発された．刺激中, 四肢筋群や躯幹筋の 動きはほとんど認められず, 刺激による効果は発声に必要 な顔面筋，舌筋，舌骨筋群に限局していた。

2. 発声時の内喉頭筋と呼吸筋の筋電図学的解析

図 2 に, 発声誘発部位に加えた電気刺激により誘発され た発声時の内喉頭筋および呼吸筋の筋電図を示す. 吸息相 の途中に開始した電気刺激により, 刺激開始後, 一過性の 吸息の延長とそれに伴う後輪状披裂筋（PCA）および横 隔膜（DA）の筋活動の増加が認められた。引き続いて甲 状披裂筋（TA）および腹直筋（RA）の筋活動の増加が認 められ, 発声が誘発された. 特に, 刺激前には弱い活動し

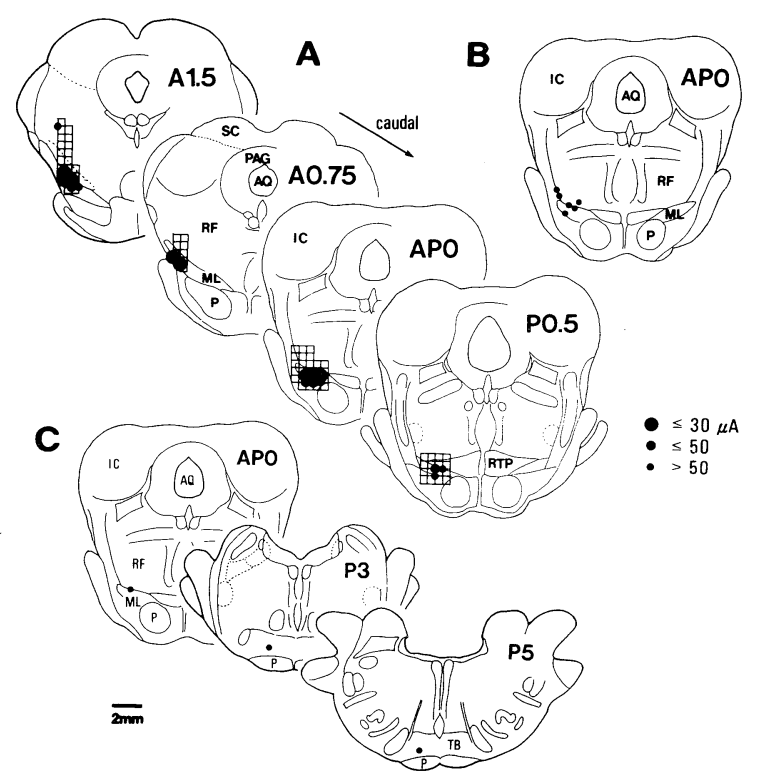

図1 A : 電気刺激を加えた部位を0.5 mm 間隔の格子で示 し, 吻側橋において発声を誘発できた部位を異なる前 額断面図上に黒丸で示す. B：6例の動物から得られ た最低閾値部位を同一前額断面図（AP 0レベル）に 黒丸で示す. C：A図と異なる動物において, 吻側橋 から尾側にかけて発声を誘発できた部位を示す. $\mathrm{AQ}$ : aqueduct; IC : inferior colliculus; $\mathrm{ML}$ : medial lemniscus; $\mathrm{P}$ : pyramidal tract; PAG : periaqueductal gray; $\mathrm{RF}$ : reticular formation; RTP : tegmental reticular nucleus; SC : superior colliculus; TB : trapezoid body 
か示さなかった声門閉鎖筋である甲状披裂筋筋活動は，刺 激により著しく増大した。また，安静呼吸時の吸息終期か ら呼息期に認められた横隔膜の弱い筋活動は声門閉鎖筋 （TA）と呼息筋筋活動の突然の増大により消失した．刺激 持続中, 吸息と発声が自発呼吸よりも延長した周期で交互 に誘発され，刺激停止とともに発声は停止した。

刺激強度および頻度の増加に従い, 内喉頭筋と呼吸筋の

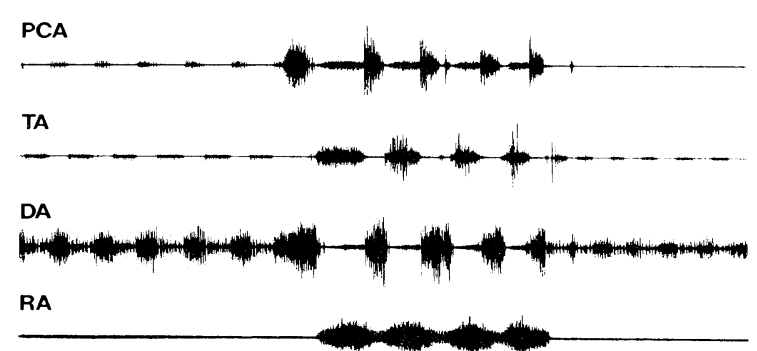

Voice

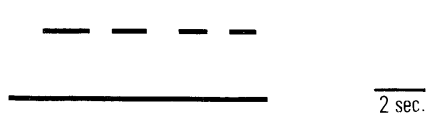

図 2 発声誘発時の内喉頭筋と呼吸筋の筋電図, および発声 の持続時間を示す. 発声誘発部位 (AP 0, R4.0, H4.5)に加えた電気刺激 $(50 \mu \mathrm{A}, 0.2 \mathrm{~ms}, 100 \mathrm{~Hz}, 10 \mathrm{~s})$ の持続時間を最下段に黒線で示す. PCA : 後輪状披 裂筋; TA : 甲状披裂筋; DA : 横隔膜 ; RA : 腹直筋

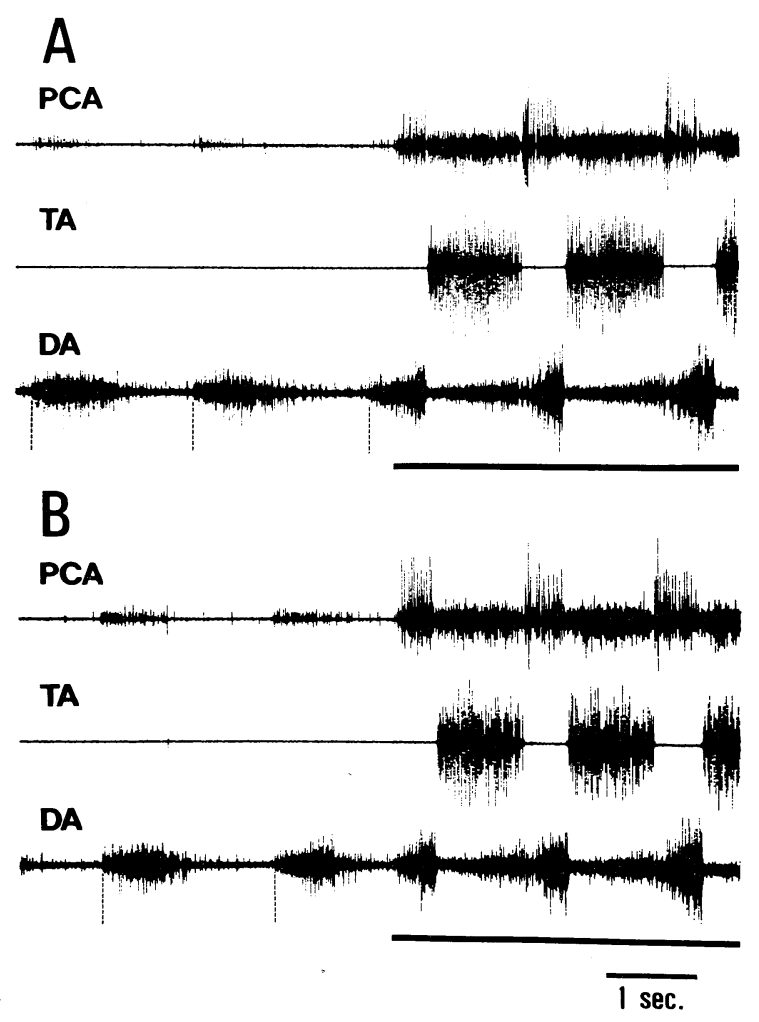

図 3 吸息相 (A) と呼息相 $(\mathrm{B})$ に刺激を開始して, 発声 を誘発した際の内喉頭筋と呼吸筋の筋電図を示す．刺 激の持続時間を最下段に黒線で示す.略称は図 2 と 同様.

筋電図活動の振幅が増大し, 誘発された発声の音量も増大 する傾向があった. 刺激側と反対側の内喉頭筋と呼吸筋の 筋電図活動を同時記録した例では, 同側と比べて, 潜時や 振幅に著明な相違は認められなかった。

次に刺激中の呼吸周期に着目すると，吸息相に開始した 刺激は吸息をある期間継続させ，その後発声を伴う呼息相 が開始した（図 $3 \mathrm{~A}$ ). 刺激強度や動物の差によって, 刺 激開始直後の吸息相がやや延長する場合もあった（図 2 ). 一方，呼息相に開始した刺激は呼息期間を短縮させ，次の 吸息の開始を早め, 発声を伴う呼吸周期を誘発した（図 3 B ). 吸息相および呼息相に開始した刺激によって誘発さ れた新しい呼吸周期を比較すると，いずれの場合も刺激開 始後ある期間の吸息が持続し，その後一定の周期で呼息相 と吸息相が繰り返し誘発された。すなわち, 脳幹に加えた 電気刺激は呼吸周期をリセットし, 吸息から始まる新しい 呼吸周期を誘発するとともに, 発声に必要な内喉頭筋と呼 吸筋の筋活動の増大を誘発することが明かであった。

3. 誘発された発声に声門下圧変化が及ぼす効果

発声を誘発した場合（図4 A ) と T-tube 気管口を開い て声門下圧の上昇を抑制した場合（図 $4 \mathrm{~B}$ ) では, 刺激前 には弱い活動しか示さなかった声門閉鎖筋（TA）筋活動 は, 刺激により著しく増大した。また, 安静呼吸時の吸息 終期から呼息期に認められた横隔膜（DA）の弱い筋活動 は声門閉鎖筋筋活動の突然の開始と共に消失した. しかし, 刺激中の呼吸周期は著しく短縮した。

次に, 発声中に T-tube 気管口を開口し, 声門下圧の上 昇を抑制し, 声門下圧の変化が呼吸周期におよぼす影響を 解析した. 発声を伴う呼息相の途中 (図 5 矢印, 呼息開始 0.44秒後) でT-tube 気管口を閉鎖した状態から開口した 場合には, 声門下圧の急激な隇少が起こり, 発声は停止し た.しかし，呼息は急激に終了することなく，ある期間の 呼息（図 5 矢印から呼息終了まで1.24秒）が持続した後, 吸息が開始した。この声門下圧の減少後に継続する呼息期

A

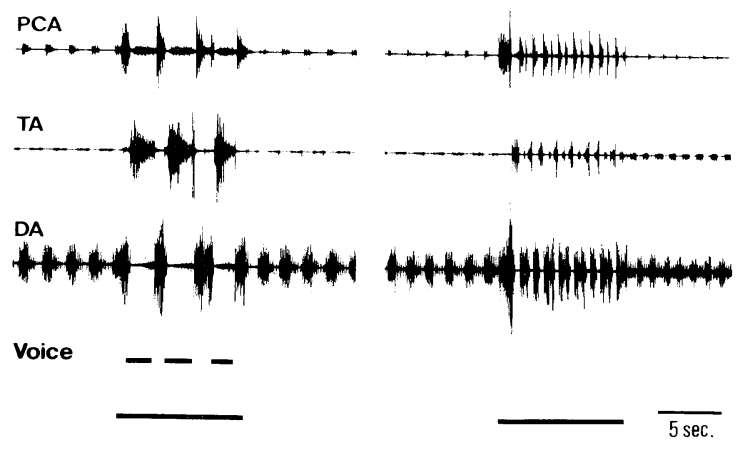

図 4 気管切開が発声誘発時の呼吸周期に及ほす効果. 同一 の動物において, T-tube 気管口を閉鎖した場合（A） および, T-tube気管口を開口した場合（B）の内喉 頭筋と呼吸筋の筋電図, および発声の持続時間を示す. 刺激の持続時間を最下段に黒線で示す. 略称は図 2 と 同様. 


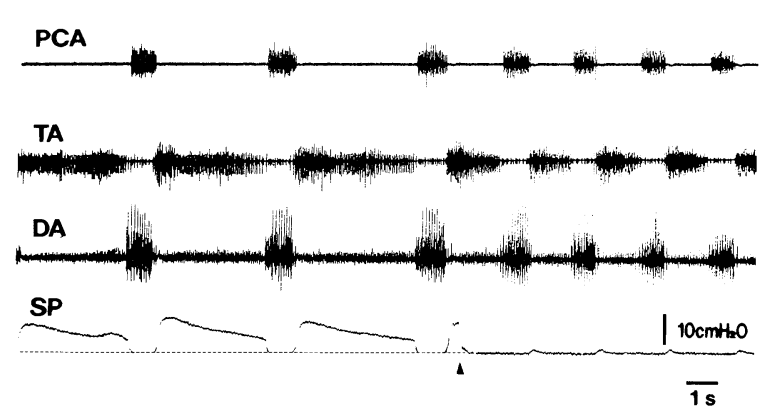

図 5 発声中に扔ける声門下圧变化の効果. 内喉頭笳と呼吸 筋の筋電図，および声門下圧の記録を示す。刺激は全 期間加えられている. 矢印は, 発声を伴う呼息相の途 中で T-tube 気管口を閉鎖した状態から開口したこと を示す. SP : 声門下圧. 他の略称は図 2 と同様.

間の長さは，T-tube気管口を開口するタイミングに依存 して変化した．呼息相の早期に開口するほど，継続する呼 息期間は延長した。図 5 において，呼息開始から矢印まで の呼息期間 $(0.44$ 秒 $)$ を T-tube 気管口を閉鎖した状態の 呼息期間 (3.6秒) を100\%として標準化したものに，矢印 から呼息終了までの呼息期間（1.24秒）を T-tube 気管口 を開口した状態の呼息期間（1.36秒）を $100 \%$ とて標準 化したものを加算すると, 103\%であった。同一の動物に おいて繰り返し行った異なる試行のいずれの場合にも，そ の和はほぼ100\%に近い值を示した. (99.4 $99.31 \%: n=6)$ 一方，発声を伴う吸息相の途中で T-tube 気管口を閉鎖 した場合には，吸息相の延長は著明ではなかった。また， 吸息相の途中で開口した場合にも同様に呼吸周期の変化は 認められなかった.

\section{考察}

上位脳幹に持続性に加えた電気刺激によって, 内喉頭筋 と呼吸筋の周期的な活動を伴う発声が誘発された。これは, 上位脳幹を含んだ上位の中枢神経機構が, 下位脳幹に存在 する内喉頭筋と呼吸筋運動に必要な基本的神経機構を統合 し，発声を発現していることを示唆する．発声誘発部位が 延髄レベルまで吻尾側方向に長く広がっていたことや, 発 声誘発部位の尾側における破壊実験や順行性標識物質等を 用いた解剖学的研究から ${ }^{12 \sim 14)}$, 発声誘発部位は内喉頭筋 支配運動ニューロンや呼吸中枢の存在する下位脳幹への下 行性経路である可能性が示唆される。

発声誘発時, 内喉頭筋と呼吸筋筋活動の増大が認められ た。この活動の増大は気管切開によって引き起こされた声 門下圧変化による求心性入力の有無に関わらず誘発された. このことは, 上位脳幹から下位脳幹に存在する内喉頭筋と 呼吸筋運動を制御する神経機構へ, 興奮性効果が及ぼされ ていることを示唆する. 橋吻側の発声誘発部位の背側部で, しばしば刺激により呼吸筋筋活動の増大のみが誘発された。 しかし, 内喉頭筋の周期的な筋活動の増大のみが誘発され た部位は存在せず, 発声誘発時は常に, 内喉頭筋と呼吸筋 筋活動の増大は同調して誘発された.このことは, 下行性
経路の一部が呼吸中枢を制御している経路と重複している 可能性を示唆する. 上位脳幹からの興奮性入力が下位脳幹 の内喉頭筋と呼吸筋運動を同一の経路を介して統合してい る可能性が推測されるが, 異なる経路で興奮性効果をもた らしている可能性も否定できない.

安静呼吸時の声帯運動に関しては, 吸息時の声門開大筋 筋活動の開始は横隔膜筋活動の開始に先行することが知ら れている ${ }^{15,16)}$. しかし, 発声誘発時には声門開大筋筋活動 の開始の先行は認められなかった. また, 安静呼吸時の吸 息終期から呼息期に認められた横隔膜の筋活動は声門閉鎖 筋と呼息筋筋活動の突然の開始と共に消失した.これらの 安静呼吸時とは異なる筋活動様式は, 気管切開によって求 心性入力を遮断して芑認められた。このことは, 発声誘発 部位に加えた上位の電気刺激は, 安静呼吸時とは異なる様 式で, 下位の内喉頭筋と呼吸筋を制御する中枢神経機構の 活動を惹起したことを示唆する.

安静時の呼吸周期は迷走神経を介する求心性入力により 制御されていること, 内喉頭筋支配運動ニューロンの興奮 性は呼吸に伴う求心性入力や喉頭粘膜からの上喉頭神経内 枝由来による求心性入力によって影響を受けることが知ら れている ${ }^{2 \sim 5,7)}$. また, 安静呼吸時の呼息流量は求心性入 力により積極的に制御されており，呼息時における突然の 気管切開は, 急速な呼気流出による肺の虚脱を防ぐために, 迷走神経由来の求心性入力によって呼吸筋活動を誘発する ことが報告されている6 ${ }^{6}$.

本研究においては, 上位脳幹に加えた電気刺激を呼吸周 期のいずれの位相に開始しても, 吸息から始まる新しい呼 吸周期が誘発された。誘発された新しい呼吸周期は, 声門 下圧上昇を抑制することによって短縮した.この求心性入 力の変化による呼吸周期短縮の原因としていくつかの可能 性が考えられる、第 1 に, 気管切開を行ったことにより声 門下圧が低下し, 喉頭粘膜や上気道からの求心性入力が減 少した.この求心性入力の減少により, 発声の中枢神経機 構が影響を受け, 呼吸周期が短縮した可能性がある。しか し, 発声の途中での声門下圧の急激な減少にもかかわらず, 呼息から吸息への急激な移行が起こらなかったことから， 喉頭粘膜や上気道からの求心性入力は余り重要ではないこ とが推測される、第 2 に, 気管切開を行ったことにより気 道抵抗が減少し, 流速が速まったために, 肺の膨張 ・収縮 時間が短縮した。ささらに, 肺の膨張時間の短縮は, 肺の伸 展 ・閉塞に関連した胸郭や肺胞の受容器からの迷走神経由 来による求心性入力の増加を惹起し, 次に起こる呼息開始 を早めた可能性がある. 実際の呼息流量を計測してはいな かったが, 標準化した呼息期間はほぼ一定であることから, 発声誘発時の呼吸周期を形成するための因子として, 肺の 伸展 ·閉塞に関連した胸郭や肺胞の受容器からの迷走神経 由来による求心性入力が重要であることが示唆される。ま た, 刺激開始直後から呼吸周期短縮が認められるので, 発 声に伴う過呼吸による低炭酸ガス状態は原因因子として可 能性が低いと考えられる. 


\section{ま と め}

1. 無麻酔除脳ネコの上位脳幹に持続性に加えた微小電気 刺激によって, 発声を伴う内喉頭筋と呼吸筋の周期的な活 動が誘発された。

2. 発声誘発部位は橋腹外側部の脳幹網様体から延髄レベ ルまで吻尾側方向に長く広がっており，上位脳幹を含んだ 上位の中枢神経機構が, 下位脳幹に存在する内喉頭筋と呼 吸筋運動を統合する基本的神経機構を制御していることが 示唆された.

3. 発声誘発時に認められた内喉頭筋と呼吸筋筋活動の振 幅や活動様式は, 安静呼吸時とは異なっていた。

4.上位脳幹に加えた電気刺激を呼吸周期のいずれの位相 に開始しても，吸息から始まる新しい呼吸周期が誘発され た。

5. 誘発された発声時の呼吸周期を形成するための因子と して, 肺の伸展 ・閉塞に関連した胸郭や肺胞の受容器から の迷走神経由来による求心性入力が重要であることが示唆 された。

\section{謝 辞}

稿を終えるにあたり, 本実験の場を提供戴き, 終始御指 導, 御助言を戴きました千葉大学医学部第一生理学教室中 島祥夫教授, 坂本尚志助教授に厚く御礼申し上げます。

本論文の要旨は, 第 4 回日本喉頭科学会において発表し た。

\section{参 考 文 献}

1) Euler CV:Brain stem mechanisms for generation and control of breathing pattern. Handbook of Physiology, (Cherniack NS and Widdicombe JG ed), sect. 3, vol II, 1 67, Am. Physiol. Soc., Washington, 1986.

2) Knox CK : Characteristics of inflation and deflation reflexes during expiration in the cat. $\mathrm{J}$ Neurophysiol 36:284 295, 1973.

3) Bartlett $\mathrm{D}$ Jr et al : laryngeal regulation of respiratory airflow. Resp physiol 18: 194 204, 1973.

4) Bartlett D Jr: Upper airway motor systems. Handbook of Physiolohgy, (Cherniack NS and Widdicombe JG ed), sect. 3, vol II , 223 245, Am. Physiol, Soc., Washington, 1986.

5) Mead J and Agostoni E: Dynamics of breath- ing. Handbook of Physiology, (Fenn VO and Rahn $\mathrm{H}$ ed ed), sect. 3, vol I, 411 427, Am. Physiol. Soc., Washington, 1964.

6) Remmers JE and Bartlett DJ : Reflex control of expiratory airflow and duration. Exercise Physiol 42: 80 87, 1977.

7) Widdicombe JG: Reflexes from the upper respiratory tract. Handbook of Physiology, (Cherniack NS and Widdicombe JG ed), sect. 3, vol II , 363 394, Am. Physiol. Soc., Washington, 1986.

8) Yamanaka $Y$ and Sakamoto $T$ : Effects of tracheostomy upon vocalization induced by midbrain electrical stimulation in decerebrate cats. Neurosci Res Suppl 16: 106, 1991.

9) Yamanaka $Y$ et al : Functional role of afferent inputs in electrically induced vocalization in decerebrate cats. Jpn J Physiol : 1992 in press.

10) de Lanerolle NC: A pontine call site in the domestic cat: Behavior and neural pathways. Neurosci $37:$ 201 214, 1990.

11) Magoun $\mathrm{HW}$ et al : Associated facial, vocal and respiratory components of emotional expression : an experimental study. J Neuro Psychopathol $17: 241 \sim 255,1937$.

12) Kanai $\mathrm{T}$ and Wang $\mathrm{SC}:$ Localization of the central vocalization mechanism in the brainstem of the cat. Exp Neurol 6:426 434, 1962.

13) Jurgens $U$ and Pratt $R$ : The cingular vocalization pathway in the squirrel monkey. Exp Brain Res 34: 499 510, 1979.

14) Holstege $G$ : Anatomical study of the final common pathway for vocalization in the cat. $J$ Comp Neurol $284:$ 242 252, 1989.

15) England SJ et al: Influence of human vocal cord movements on airflow and resistance in eupnea. J Appl Physiol 52:773 779, 1982.

16) St John WM et al: Brainstem genesis of automatic ventilatory patterns independent of spinal mechanisms. J Appl Physiol 51 : 204 210, 1981.

別刷請求先 干260 千葉市中央区亥鼻 1 丁目8-1 千葉大学医学部耳鼻咽喉科学教室 山中康久 